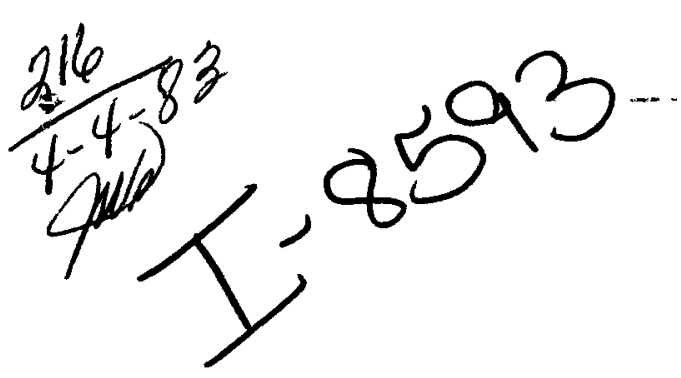

(1) D. D. 1294

MLM-3039

\title{
Diallyl Phthalate Prepolymer \\ Characterization and Testing in Fiberglass Filled Molding Compounds
}

Ruth B. Whitaker, Robert E. Schneider and

Roy J. Schumacher

February 21, 1983

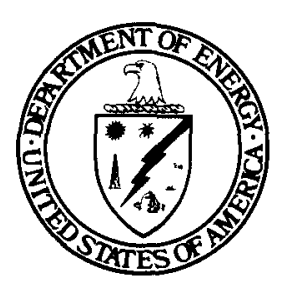

Monsanto

\section{MOUND}

Miamisburg, Ohio 45342

operated by

MONSANTO RESEARCH CORPORATION

a subsidiery of Monsento Company

for the

U. S. DEPARTMENT OF ENERGY

Contract No.DE-ACO4-76-DPOOOS3 


\section{DISCLAIMER}

This report was prepared as an account of work sponsored by an agency of the United States Government. Neither the United State's Government nor any agency thereof, nor any of their employees, makes any warranty, express or implied, or assumes any legal liabili. ty or responsibility for the accuracy, completeness, or usefulness of any information, apparatus, product, or process disclosed, or represents that its use would not infringe privately owned rights. Reference herein to any specific commercial product, process, or service by trade name, trademark, manufacturer, or otherwise, does not necessarily constitute or imply its endorsement, recommendation, or favoring by the United States Government or any agency thereof. The views and opinions of authors expressed herein do not necessarily state or reflect those of the United States Government or any agency thereof.

Printed in the United States of America

Available from

National Technical Information Service

U. S. Department of Commerce

5285 Port Royal Road

Springfield, VA 22161

NTIS price codes

Printed Copy: A02

Microfiche copy: $\mathrm{A} 01$ 


\section{DISCLAIMER}

This report was prepared as an account of work sponsored by an agency of the United States Government. Neither the United States Government nor any agency Thereof, nor any of their employees, makes any warranty, express or implied, or assumes any legal liability or responsibility for the accuracy, completeness, or usefulness of any information, apparatus, product, or process disclosed, or represents that its use would not infringe privately owned rights. Reference herein to any specific commercial product, process, or service by trade name, trademark, manufacturer, or otherwise does not necessarily constitute or imply its endorsement, recommendation, or favoring by the United States Government or any agency thereof. The views and opinions of authors expressed herein do not necessarily state or reflect those of the United States Government or any agency thereof. 


\section{DISCLAIMER}

Portions of this document may be illegible in electronic image products. Images are produced from the best available original document. 
MLM-3039

UC-25

MISI- -3039

DE83 009352

\title{
Diallyl Phthalate Prepolymer Characterization and Testing in Fiberglass Filled Molding Compounds
}

\author{
Ruth B. Whitaker, Robert E. Schneider and \\ Roy J. Schumacher
}

Issued: February 21, 1983

DISCLAIMER

This report was prepared as an account of work sponsored by an agency of the United States Government. Neither the United States Government nor any agency thereof, nor any of their employees, makes any warranty, express or implied, or assumes any legal liability or responsibility for the accuracy, completeness, or usefulness of any information, apparatus, product, or process disclosed, or represents that its use would not infringe privately owned rights. Reference herein to any specific commercial product, process, or service by trade name, trademark, manufacturer, or otherwise does not necessarily constitute or imply its endorsement, recommendation, or favoring by the United States Government or any agency thereof. The views and opinions of authors expressed herein do not necessarily state or reflect those of the United States Government or any agency thereof.

\author{
MOUND \\ Miamisbung, Ohio 45342 \\ operated by \\ MONSANTO RESEARCH CORPORATION \\ a subsidiary of Monsanto Company \\ for the \\ U. S. DEPARTMENT OF ENERGY \\ Contract NO. DE-ACD4-7G-DPODO53
}




\section{Contents}

ABSTRACT. . . . . . . . . . . . . . . . . 3

1. INTRODUCTION. . . . . . . . . . . . . . . . 3

2. EXPERIMENTAL METHODS. . . . . . . . . . . . . . . . 4

2.1 Prepolymer Characterization. . . . . . . . . . 4

2.2 Prepolymer Processing into Molding Compounds . . . . 6

2.3 Physical/Chemical Testing of Molding Compounds . . . . 7

3. RESULTS AND DISCUSSIONS . . . . . . . . . . . . . . 8

3.1 Characterization of the DAP Prepolymers. . . . . . 8

3.2 Processibility of DAP Prepolymers. . . . . . . . . 9

3.3 Physical/Chemical Testing of DAP-FG Molding

Compounds. . . . . . . . . . . . . . 13

3.4 Conclusions. . . . . . . . . . . . . . 14

4. FUTURE WORK . . . . . . . . . . . . . . . 17

5. ACKNOWLEDGEMENTS. . . . . . . . . . . . . 18

REFERENCES. . . . . . . . . . . . . . . . . 18

DISTRIBUTION. . . . . . . . . . . . . . . . . 19 


\section{Abstract}

This report describes a program undertaken at Mound to identify an acceptable alternative to Dapon 35, an o-diallyl phthalate (DAP) prepolymer no longer available from the manufacturer.

Three o-DAP prepolymers from the Osaka Soda Company and four laboratory-scale prepolymers from Bendix-Kansas City were characterized and evaluated in DAP-fiberglass molding compounds.

Gel permeation chromatography results for the Osaka, prepolymers showed all three to be very close to one another in molecular weights and molecular weight distributions, but slightly lower in both than Dapon 35. They are also slightly higher in monomer content. All three processed readily into DAP-fiberglass molding compounds and passed required physical property tests. In addition, one osaka prepolymer was compounded into both asbestos and orlon-DAP compounds on a production scale. To date, both compounds have passed all certification tests.

The Bendix prepolymers were deliberately varied in molecular weights and molecular weight distribution; also, most were significantly higher in monomer content than Dapon 35. Processing difficulties were encountered with both the lowest and highest molecular weight compounds, and the lowest molecular weight compound failed a number of physical property tests. The two intermediate molecular weight compounds processed readily and passed property tests. Based on these results, approximate guidelines could be established for acceptable o-DAP prepolymers as follows: 1) weight average molecular weights (relative to polystyrene standards): $30,000 \leq \mathrm{M}_{\mathrm{w}} \leq$ 150,000; 2) molecular weight distribution (relative to polystyrene standards): $3.0 \leq \mathrm{M}_{\mathrm{W}} / \mathrm{M}_{\mathrm{n}} \leq 18.0$; and 3) DAP monomer content: 1.0 $\leq$ DAP monomer weight $8 \leq 6.0$.

\section{Introduction}

In 1980, FMC Corporation discontinued their manufacture of diallyl phthalate (DAP) prepolymers. To that time, Mound had employed FMC's Dapon 35 o-DAP in the production of asbestos-filled and orlonfilled DAP molding compounds. Having lost its supplier, Mound launched a search for a new domestic supplier of DAP preploymers in late 1980. No supplier was found, however. In fact, the world's sole supplier of the prepolymer appeared to be Osaka Soda Company of Japan.

Samples of three different lots of Daiso 35, the Osaka o-DAP prepolymer, were obtained from a U. S. DAP molding compound manufacturer for characterization and testing in DAP-fiberglass (FG) molding compounds. But, because relying on a 
foreign supplier for the prepolymer was considered undesirable, Bendix-Kansas City Division ( $\mathrm{BKC}$ ), the primary polymer production facility for DOE, was requested to study the feasibility of synthesizing DAP prepolymer. Laboratory-scale synthesis and characterization of the prepolymers produced at Bendix has been reported [1], and four of the prepolymers prepared there have been evaulated in DAP-fiberglass molding compounds at Mound.

This report describes Mound's efforts to characterize three Osaka Soda o-DAP prepolymers and four BKC prepolymers. The report details the characterization, done primarily by gel permeation chromatography (GPC), the processing of the prepolymers into DAP-FG molding compounds, and the physical/chemical testing of the molding compounds. A FMC Dapon 35 o-DAP prepolymer (and fiberglass molding compound) served as a standard for comparison.

\section{Experimental Methods}

\subsection{Prepolymer Characterization}

The complexity of producing "good" DAP molding compounds has been discussed previously [2]. The stages of DAP polymerization, from o-DAP monomer to final molded product, are illustrated in Figure 1. Factors in the DAP prepolymer of importance to its further compounding and molding are: 1) molecular weight and molecular weight distributions; 2) residual DAP monomer content (because of the low degree of conversion, some will inevitably be present); and 3) the pendant, or polymerizable, allyl content. The methods used for determining the first two of these (molecular weight and monomer content) are described below.
Monomer analysis was performed by liquid chromatography (LC), using GPC columns. Two HSTYRAGEL columns, obtained from the Waters Company, covered the range from 100 and 5008. The spectra-Physics $8000 \mathrm{~B}$, high performance liquid chromatograph (HPLC), was operated at a flow rate of $2 \mathrm{~mL} / \mathrm{min}$ of tetrahydrofuran (THF), resulting in an operating pressure of less than 600 psi. Chart speed was $1 \mathrm{~cm} / \mathrm{min}$ with an attenuation setting of $10 \mathrm{mV}$ full scale. The detector, a Kratos 770 UV-visible absorbance type, was operated at $250 \mathrm{~nm}$, a wavelength which obtained an adequate response from monomer and polymer. The detector sensivitity was 0.02 absorbance units full scale. DAP monomer, obtained from MCB Reagents, was used as a standard. The detector response to the monomer, using peak height measurements, was shown to be linear up to $5.8 \mathrm{\mu g}$ of monomer - very measurable relative to the detection limit of about $0.04 \mathrm{\mu g}$ of monomer.

Molecular weight analyses were carried out on the same equipment, except four USTYRAGEL Columns were used covering the ranges of $10^{6}, 10^{5}, 10^{4}$ and $500 \AA$. A flow rate for THF of $1.0 \mathrm{~mL} / \mathrm{min}$ was used, resulting in an operating pressure of about $500 \mathrm{psi}$. The instrument's data system is programmed for molecular weight analyses by integration of the area under the curve in discrete seqments of selectable size. A segment size of $20 \mathrm{sec}$ was chosen. The inaccuracies, resulting from integration of baseline noise, were minimized by selecting a minimum recordable area of 2000 area counts. In addition, errors of great magnitude, resulting from the integration of noise in the very short retention time (high molecular weight) areas, 


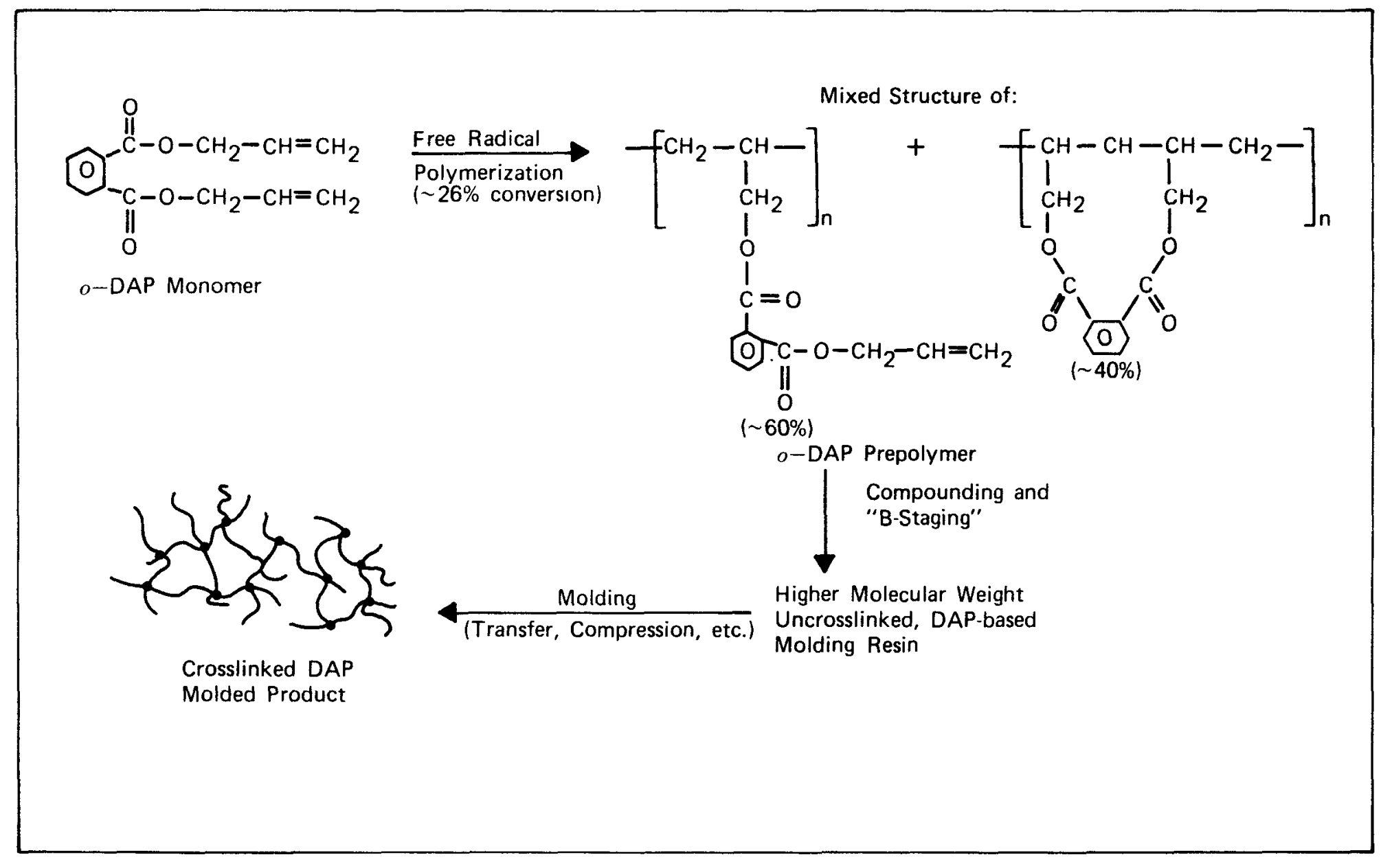

FIGURE 1 - Stages of o-DAP polymerization from monomer to molded part. 
are eliminated by setting an appropriate integration initiation time. Sample solutions were prepared at concentrations of about $2 \mathrm{mg} / \mathrm{mL}$, although there is no need to prepare them quantitatively. All settings on the detector and recorder were the same as in the monomer analysis. standards of monodisperse polystyrene were used because they were readily available and because we expected this material to have characteristics similar to those of DAP. GPC measures molecular size, not weight. If DAP and polystyrene have significantly different size-to-weight ratios, significant differences would occur in the absolute value of the molecular weight values assigned to DAP. Although the absolute value of the molecular weight is of minor importance, comparisons of assigned molecular weight numbers, relative to other DAP prepolymers, are certainly valid and meaningful.

A calibration is run by injecting the standards of known molecular weight and entering the corresponding retention times (RT) into the data system. Then, without altering the flow rate, the samples are injected. The data system correlates the sample's integration for each of these retention time segments with the corresponding molecular weight and calculates the weight average molecular weight, $\left(\mathrm{M}_{\mathrm{w}}\right)$, number average molecular weight, $\left(M_{n}\right)$, and the molecular weight distribution, (MWD), or $\mathrm{M}_{\mathrm{w}} / \mathrm{M}_{n}$. The values obtained in these calculations depend on the shape of the chromatogram. The shape is dependent on the condition of the HPLC column. Erosion of the surface of the sorbent, or partial plugging of some areas of the column, or mere differences in packing efficiencies will cause variations from column to column or from time to time within a column. Hence, very precise results are not the normal output of these analyses; somewhat greater variance must be expected.

\subsection{Prepolymer Processing into Molding Compounds}

The DAP prepolymers, as received, were all white powders. These were then compounded into DAP-FG molding resins as follows:

(1) The DAP polymer was dissolved in acetone (amounts varied) in a small ( 2 gal) sigma bladetype Day mixer $\left(90-100^{\circ} \mathrm{F}\right.$ inlet $\mathrm{H}_{2} \mathrm{O}$ temperature maintained to the jacketed mixer).

(2) After dissolution, the other components were added, with the fiberglass and cofiller being added last (with a small, additional amount of acetone, if needed).

(3) After mixing $\sim 15 \mathrm{~min}$, the solvent was removed by vacuum.

(4) The DAP-FG mixture was milled immediately on a 2-roll mill, until the temperature of the DAP-FG sheet had reached $\sim 100-$ $110^{\circ} \mathrm{C}$ for $\sim 10 \mathrm{~min}$ (roll temperatures were $92 / 56^{\circ} \mathrm{C}$ ).

(5) The milled DAP-FG compound was cooled to room temperature, ground through a $1 / 2$ in. screen, and air-dried $\geq 24 \mathrm{hr}$ before further processing.

(6) If needed, additional "Bstaging" was accomplished in a vented oven for varying times/ temperatures. After all "Bstaging"/drying was complete, the DAP-FG molding compounds were kept refrigerated until tested further. 
Whether additional "B-staging" was required after milling was decided on the basis of differential scanning calorimeter (DSC) determination of the heat of reaction $\left(\Delta \mathrm{H}_{\mathrm{R}}\right)$, and thermogravimetric (TGA) determination of the molding compound's inorganic (ash) content, in comparison with results obtained for the "standard" FMC Dapon 35 prepolymer-fiberglass compound. This ensured all compounds were prepared to approximately the same degree of cure.

The standard formulation used for all of the DAP-FG molding compounds is given in Table I, for the FMC Dapon 35-FG compound. Wherever any formulation variations were made, these will be indicated.

\subsection{Physical/Chemical Testing of Molding Compounds}

The finished DAP-FG molding compounds were tested following the same ASTM test procedures used for shortglass-DAP molding compound certification at Mound; all the tests normally run for certification, as well as some additional tests, were performed. Because materials were limited, the number of test specimens was limited to 2 specimens per test, unless otherwise indicated. In only one test (arc resistance) was any substantial variability encountered in results between test specimens; however, this was also experienced with DAP-FG resins other than those of this report. Hence, the cause is believed not to be related to the DAP prepolymers used.

Other tests performed (in addition to the standard certification tests, as given

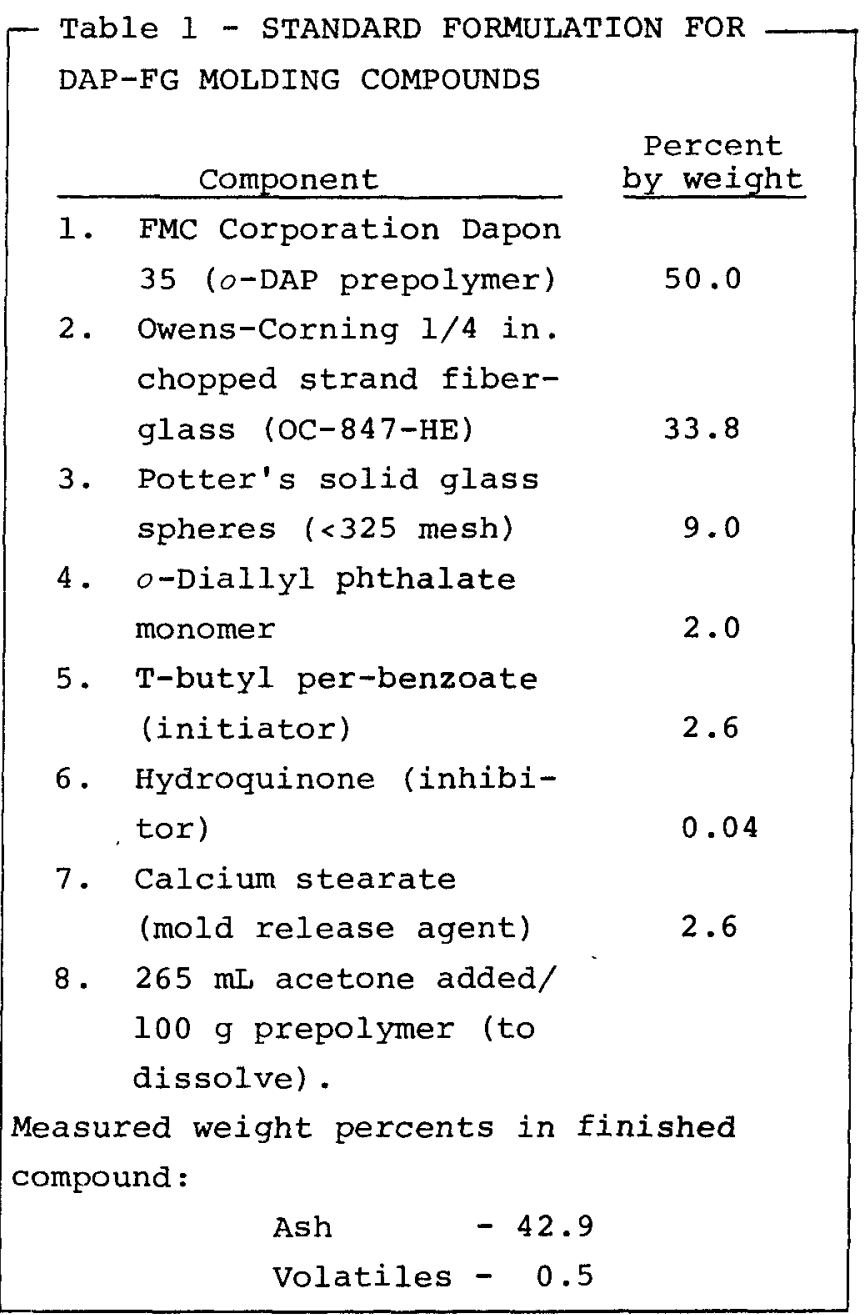

in Mound Specification No. 1-14741) and methods used were as follows:

1) Total chloride (including bromide) analysis - ASTM D-808 (Parr Bomb) and free $\mathrm{Cl}^{-}$- ion chromatograph.

2) Volatiles $-4 \mathrm{hr} / 105^{\circ} \mathrm{C}$ oven.

3) Ash contents (2 methods with an agreement of better than $\pm 1.0 \%$ ); (a) thermogravimetric analysis (TGA) using 20-30 $\mathrm{mg}$ sample size and a DuPont 951 TGA/1090 thermal analyzer - programmed at $20^{\circ} \mathrm{C} / \mathrm{min}$ from 50 $1000^{\circ} \mathrm{C}$ (in $\mathrm{N}_{2}$ ); ash is residue at $1000^{\circ} \mathrm{C}$; and (b) standard gravimetric analysis (to $900^{\circ} \mathrm{C}$ ). The latter results are cited. 
4) Heats of Reaction - Differential Scanning calorimetry (DSC) determination on 15-30 $\mathrm{mg}$ pellets prepared according to the method of Willard [3]; DuPont 910 DSC/1090 thermal analyzer used - programmed at $20^{\circ} \mathrm{C} /$ min from $50-250^{\circ} \mathrm{C}$ (in $\mathrm{N}_{2}$ ); indium calibration standard used.

5) Elemental Analyses - emission spectroscopy was used to determine whether excess amounts of any potentially undesirable elements were present.

6) Mesa spiral Flow - this is a certification test used to determine the suitability of a given DAP-FG resin for molding into a particular configuration. Thus, there is an allowable range for each product, but no overall limits or range of acceptable values. It is possible to alter spiral flow as needed, by adjusting factors such as DAP monomer content or amount of "B-staging."

\section{Results and Discussions}

The results will be considered in three parts: (1) characterization of the DAP prepolymers; (2) processability of the prepolymers; and (3) physical/chemical testing of the prepolymers. Finally, some conclusions will be given on some of the characteristics required for DAP prepolymers to make "good" molding compounds.

\subsection{Characterization of the DAP Prepoly- mers}

Many variables of the polymerization and product isolation processes affect the molecular weight of the polymer. Among these are the initiator, the chain transfer agent, the extent of monomer conver- sion, and the method of isolation. The function of this project is not to study the effect of all these variables, but to find a highly consistent, usable product.

At this time, the primary characterization data on all of the DAP prepolymers available are: molecular weights and molecular weight distribution (MWD) and DAP monomer contents. These results are summarized in Table 2. The molecular weight distributions are shown graphically by the GPC chromatograms reproduced in Figure 2 and Figure 3.

A number of features about the molecular weights and molecular weight distributions of these prepolymers should be noted. First is the broadness of all the molecular weight distributions, except for the very lowest molecular weight $B K C$ prepolymer. Second, the three Osaka prepolymers appear to be reasonably close to one another (especially samples from lots 7421 and 8566 ) and only somewhat lower in weight average molecular weights $\left(M_{W}\right)$ and MWD than Dapon 35. This is shown in Figure 2. The vertical lines and numbers correspond to the molecular weights of the monodisperse polystyrene standards. Because the weight average molecular weight is very sensitive to the presence of shorter retention time (or higher molecular weight) material, the MWD of the FMC prepolymer is larger than that of the Osaka prepolymers. Otherwise, all have a similar bimodaltype chromatogram.

The molecular weight distributions of the four BKC prepolymers, shown in Figure 3, are very different from one another and 
Table 2 - MOLECULAR WEIGHT DISTRIBUTIONS AND MONOMER CONTENTS OF DAP PREPOLYMERS

\section{- $\frac{\text {-DAP Prepolymer }}{\text { Source }}$ \\ FMC Corporation Dapon 35}

(QC 23797)

Osaka Soda of Japan City

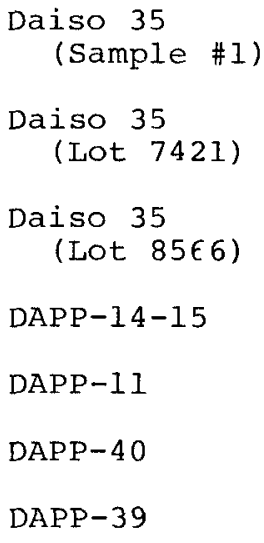

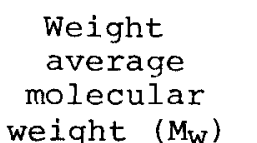

$$
68,000
$$$$
34,400
$$

48,300

50,800

8100

30,900

144,600

631,000

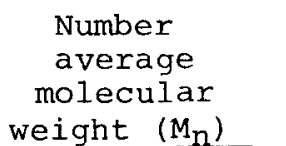

6200

7200

6900

7400

4200

6700

8700

9800

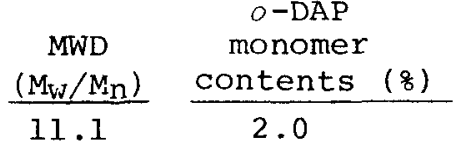

4.8

2.7

7.0

2.5

6.9

2.5

1.9

6.9

4.6

2.6

16.6

5.1

64.7

4.2 from the FMC prepolymer. This is the result of an effort by BKC to synthesize DAP prepolymers of widely varying molecular weights in order to be able to correlate molecular weight with processing and properties. An explanation of the resultant prepolymer molecular weights, in relation to the o-DAP polymerization process, has been given [1].

Of the BKC prepolymers, the DAPP-11 corresponds most nearly to the osaka prepolymers, whereas the FMC prepolymer is intermediate between DAPP-II and DAPP-40. The DAPP-39 has a substantial amount of high molecular weight (short retention time) material and therefore a very high $\mathrm{M}_{\mathrm{w}}$ value. $\mathrm{BKC}-14-15$ is the lowest in $\mathrm{M}_{W}$ and MWD of any of the prepolymers.

The DAP monomer contents of the three osaka prepolymers are all slightly higher than FMC's Dapon 35, and very close to one another. The DAP monomer content of most of the BKC prepolymers is signif- icantly higher than that of the FMC prepolymer. This can be an important factor in the compounding, because some additional monomer is generally added to assist in the final crosslinking reaction on molding. However, the amount added (if any) can be adjusted to fit the monomer content of the starting prepolymer. In this study, for the "standard" formulation (Table 1), 2.0\% DAP monomer was added in all cases, at least initially.

\subsection{Processability of DAP Prepolymers}

All of the o-DAP prepolymers were processed into DAP-FG molding compounds in a similar manner, as described previously, using the "standard" formulation given in Table 1 . Any variations, particularly in the "B-staging", and the observations made on the relative ease of processing the different prepolymers are given in Table 3 . As described, DSC was used to determine heats of reaction $\left(\Delta_{R}\right)$ to decide 


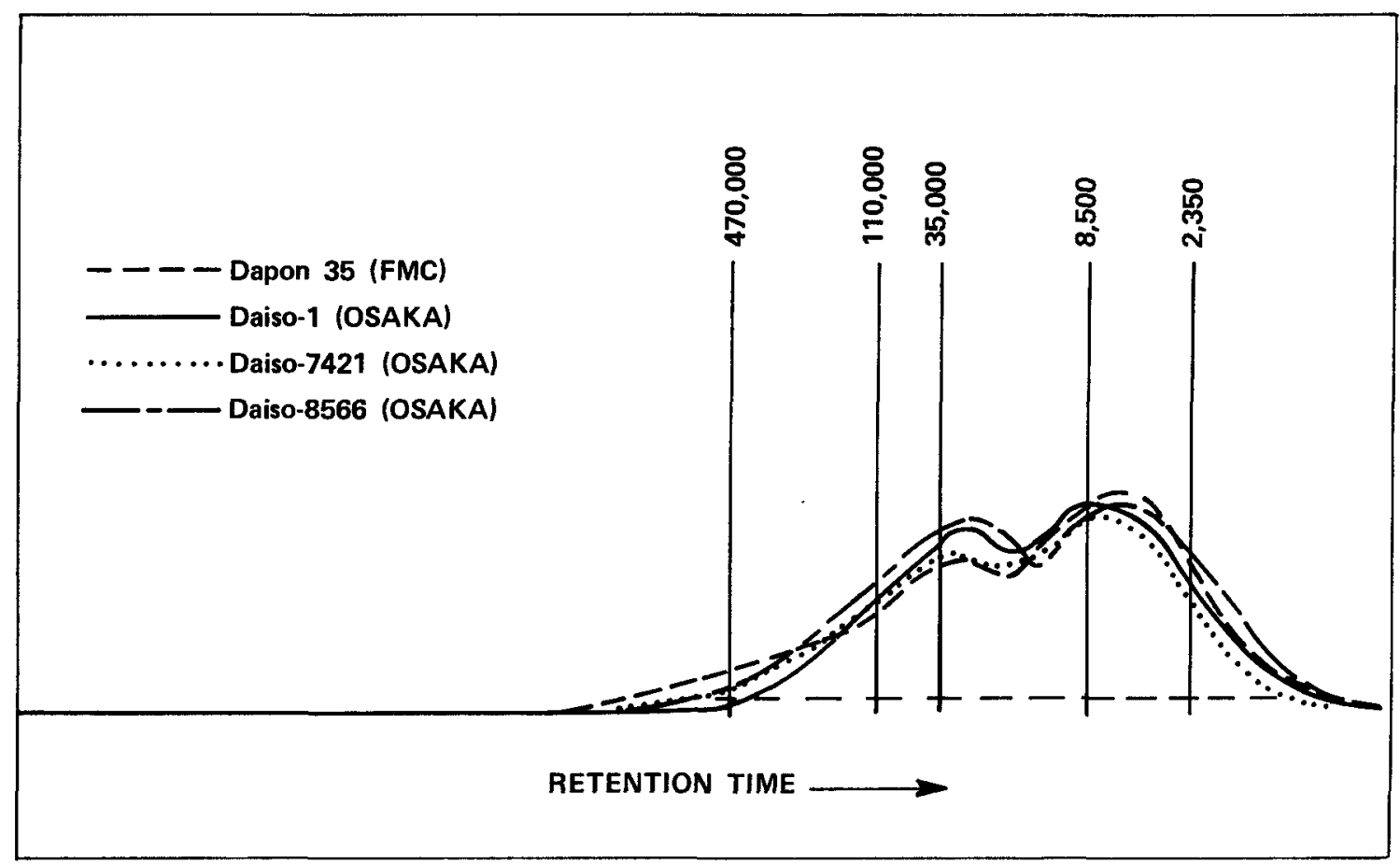

FIGURE 2 - Similarity in molecular weight distributions of FMC and Osaka DAP prepolymers shown by GPC. (Numbers correspond to molecular weights of polystyrene standards.)

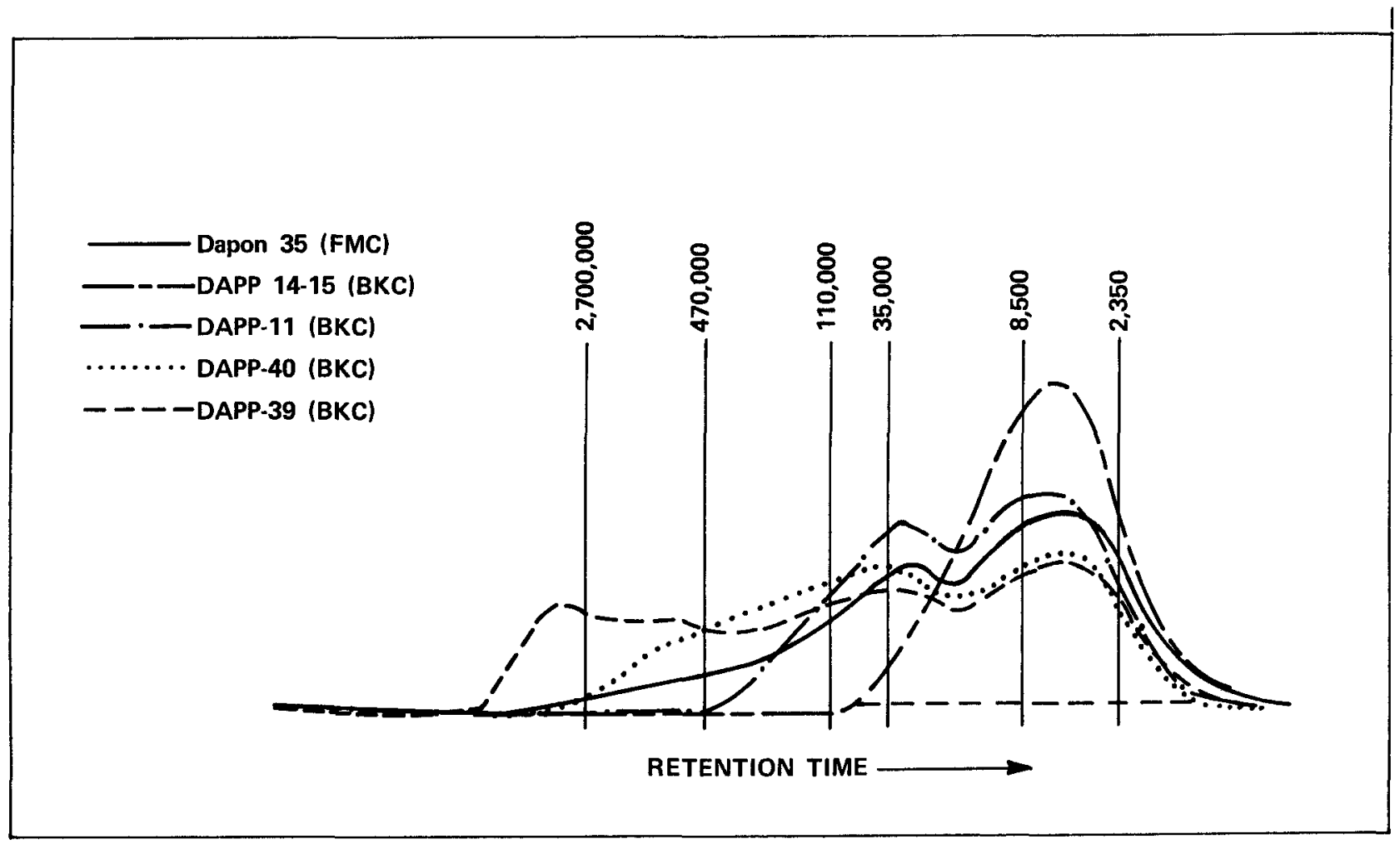

FIGURE 3 - Wide range of molecular weight distributions of BKC DAPP prepolymers shown by GPC. (Numbers correspond to molecular weights of polystyrene standards.) 
Table 3 - PROCESSABILITY OF O-DAP PREPOLYMERS

IN "STANDARD" DAP-FIBERGLASS MOLDING COMPOUND ${ }^{a}$

\begin{tabular}{|c|c|c|c|c|c|c|}
\hline \multicolumn{2}{|l|}{$-\ldots$} & STANDARD" & \multicolumn{4}{|c|}{ DAP-FIBERGLASS MOLDING COMPOUND ${ }^{\mathrm{a}}$} \\
\hline \multicolumn{2}{|c|}{ o-DAP prepolymer } & \multirow{2}{*}{$\begin{array}{l}\text { Molding } \\
\text { compound } \\
\text { number }\end{array}$} & $\begin{array}{l}\text { Proc } \\
\text { Acetone } \\
\text { to dissolve } \\
100 \mathrm{~g} \text { of } \\
\text { prepolymer }\end{array}$ & sing conditions ${ }^{b}$ & \multirow{2}{*}{$\begin{array}{l}\text { Pheometer } \\
\text { minimum } \\
\text { torque } \\
\text { (ft/1b) and } \\
8 \mathrm{max} / 3 \mathrm{~min} \\
\end{array}$} & \multirow{2}{*}{$\begin{array}{c}\text { Ease of } \\
\text { procossability }\end{array}$} \\
\hline Source & Designation & & $(\mathrm{mL})$ & B-Staging/drying & & \\
\hline FMC Corporation & $\begin{array}{l}\text { Dapon } 35 \\
(M d . Q C \# \\
23797)\end{array}$ & 554 & 265 & $\begin{array}{l}\text { 1. Mill } 25 \mathrm{~min} \text { (to } 100^{\circ} \mathrm{C} \text { ) } \\
\text { 2. Dry } 6 \text { days } / \mathrm{RT} \\
\text { 3. Oven "B-stage" } 30 \mathrm{~min} / \\
\quad 95-103^{\circ} \mathrm{C} \\
\text { 4. Dry } 2 \mathrm{hr} / 55-60^{\circ} \mathrm{C}\end{array}$ & $5 / 958$ & Excellent \\
\hline \multirow[t]{4}{*}{$\begin{array}{l}\text { Osaka Soda of } \\
\text { Japan }\end{array}$} & $\begin{array}{l}\text { Daiso } 35 \\
\text { 1. Sample \#1 }\end{array}$ & 565 & 265 & $\begin{array}{l}\text { 1. Mill } 25 \min \text { (to } 110^{\circ} \mathrm{C} \text { ) } \\
\text { 2. Dry } 1 \text { day/RT }\end{array}$ & $4 / 978$ & Excellent \\
\hline & 2. Iot 7421 & 576 & 265 & $\begin{array}{l}\text { 1. Mill } 25 \min \left(\text { to } 104^{\circ} \mathrm{C} \text { ) }\right. \\
\text { 2. Dry } 1 \text { day/RT }\end{array}$ & $4 / 998$ & Excellent \\
\hline & 3. Iot 8566 & $577^{C}$ & 265 & $\begin{array}{l}\text { 1. Mill } 25 \mathrm{~min} \text { (to } 104^{\circ} \mathrm{C} \text { ) } \\
\text { 2. Dry } 2 \text { days/RT } \\
\text { 3. Oven "B-Stage" } 20 \mathrm{~min} / \\
\text { 100-105 C }\end{array}$ & $3 / 93^{\mathrm{d}}$ & $\begin{array}{l}\text { Good - some } \\
\text { difficulty in } \\
\text { milling }\end{array}$ \\
\hline & 4. Lot 8566 & 581 & 265 & $\begin{array}{l}\text { 1. Mill } 20 \min \left(\text { to } 109^{\circ} \mathrm{C} \text { ) }\right. \\
\text { 2. Dry } 1 \text { day/RT } \\
\text { 3. Oven "B-Stage" } 25 \mathrm{~min} / \\
95-105^{\circ} \mathrm{C}\end{array}$ & $4 / 928$ & Excellent \\
\hline \multirow[t]{4}{*}{$\begin{array}{l}\text { Bendix - Kansas } \\
\text { City (BKC) }\end{array}$} & 1. DAPP-14- & 578 & 265 & $\begin{array}{l}\text { 1. Mill } 40 \mathrm{~min}\left(\leq 100^{\circ} \mathrm{C}\right) \\
\text { 2. Dry } 4 \text { days/RT" } \\
\text { 3. Oven "B-Stage" } 30 \mathrm{~min} / \\
100-105^{\circ} \mathrm{C}\end{array}$ & $2 / 938^{d}$ & $\begin{array}{l}\text { Poor - very } \\
\text { difficult to } \\
\text { mill }\end{array}$ \\
\hline & $\begin{array}{l}\text { 2. DAPP-14- } \\
15\end{array}$ & $580^{e}$ & 215 & $\begin{array}{l}\text { 1. Mill } 40 \mathrm{~min} \text { (to } 104^{\circ} \mathrm{C} \text { ) } \\
\text { 2. Dry } 1 \text { day/RT } \\
\text { 3. Oven "B-Stage" } 40 \mathrm{~min} / \\
105-115^{\circ} \mathrm{C}\end{array}$ & 9/938 & $\begin{array}{l}\text { Poor - difficult } \\
\text { to mill }\end{array}$ \\
\hline & 3. DAPP-11 & 575 & 265 & $\begin{array}{l}\text { 1, Mill } 25 \min \text { (to } 104^{\circ} \mathrm{C} \text { ) } \\
\text { 2. Dry I day/RT }\end{array}$ & $4 / 1008$ & Excellent \\
\hline & 4. $D A P P-40$ & 582 & 340 & $\begin{array}{l}\text { 1. Mill } 25 \min \text { (to } 108^{\circ} \mathrm{C} \text { ) } \\
\text { 2. Dry } 1 \text { day/RT } \\
\text { 3. Oven "B-Stage" } 30 \mathrm{~min} / \\
100-105^{\circ} \mathrm{C}\end{array}$ & $5 / 978$ & Excellent \\
\hline $\begin{array}{l}\text { Bendix - Kansas } \\
\text { Clty (BKC) }\end{array}$ & 5. DAPP-39 & 583 & 340 & $\begin{array}{l}\text { 1. Mill } 25 \mathrm{~min} \\
\text { 2. Dry } 2 \text { days } / \mathrm{RT}\end{array}$ & 4/978 & $\begin{array}{l}\text { Fair - diffi- } \\
\text { cult to dis- } \\
\text { solve }\end{array}$ \\
\hline \multicolumn{7}{|c|}{$\begin{array}{l}\text { asee Table } 1 \text { for "standard" formulation. } \\
\text { bsee text for details. } \\
\text { Geight percent fiberolass }\end{array}$} \\
\hline
\end{tabular}


whether additional oven "B-staging" was required after milling to achieve about the same degree of cure for all molding compounds. This is illustrated in Figure 4, which compares the $\Delta \mathrm{H}_{\mathrm{R}}$ 's of Compound \#582 (BKC-DAPP-40 prepolymer) after milling and after subsequent oven "Bstaging." In addition to reducing $\Delta H_{R}$, there is also a slight lowering of the onset polymerization temperature (from $\sim 140$ to $\sim 128^{\circ} \mathrm{C}$ ), probably resulting from the loss of inhibitor during oven "B-staging."

The three Osaka prepolymers all processed readily in the "standard" formulation and passed the required oscillating disc rheometer minimum torque test.
(All compounds were deliberately kept to the lower end of the 4-15 ft/lb allowable range in order to avoid the possibility of overprocessing and crosslinking before molding.) With only one Osaka prepolymer, prepared with an alternate fiberglass, was any problem encountered. The formulation and/or conditions used may not have been optimal for this particular FG, and no further attempt was made to use this fiberglass during this study.

Considerably more variation was noted in the processibility of the BKC prepolymers, as might be expected from the differences in molecular weights. The lowest molecular weight polymer (DAPP-14-15) was difficult to mill and difficult to process, in order

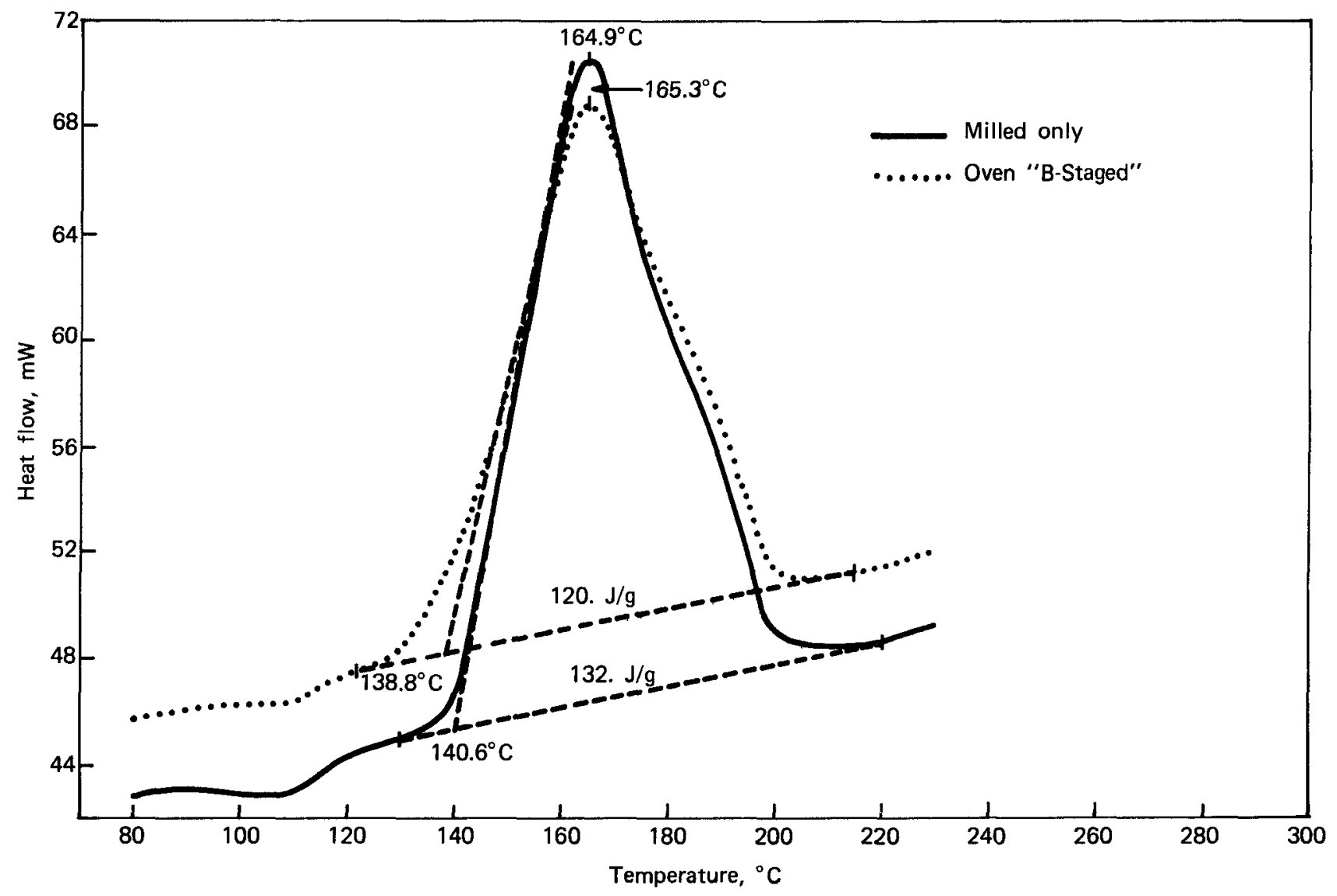

FIGURE 4 - DSC shows oven "B-Staging" after milling reduces $\triangle H_{R}$ of DAP-FG molding compounds from $132 \mathrm{~J} / \mathrm{g}$ to $120 \mathrm{~J} / \mathrm{g}$. Comparable sample amounts ( 20 mg) used. 
to achieve a reasonable degree of cure. Even a second formulation (without any added monomer, using less solvent, and with additional fiberglass and catalyst) was also difficult to mill and did not yield a satisfactory product. Although it had passed the rheometer minimum torque test, its DSC thermogram (Figure 5) shows that it begins to cure at a relatively low temperature $\left(110^{\circ} \mathrm{C}\right)$. This would be undesirable in a transfer molding operation. Additional inhibitor to prevent this premature cure cannot be added as this would only further inhibit the required "B-Staging" polymerization. Thus, the molecular weight of this prepolymer is probably too low to enable it to be made into a useful molding compound in any formulation.

The two intermediate molecular weight $\mathrm{BKC}$ prepolymers (DAPP-11 and DAPP-40) processed readily, although additional solvent was used to dissolve the DAPP-40. Even with added solvent, the highest molecular weight prepolymer (DAPP-39) was difficult to dissolve. Traces of it were found on the mixer walls after processing, suggesting that not quite all of it was dissolved. The two intermediate $\mathrm{M}_{\mathrm{w}} \mathrm{BKC}$ prepolymers were definitely preferable from a processing standpoint.

\subsection{Physical/Chemical Testing of DAP-FG Molding Compounds}

The physical properties of all the DAP-FG

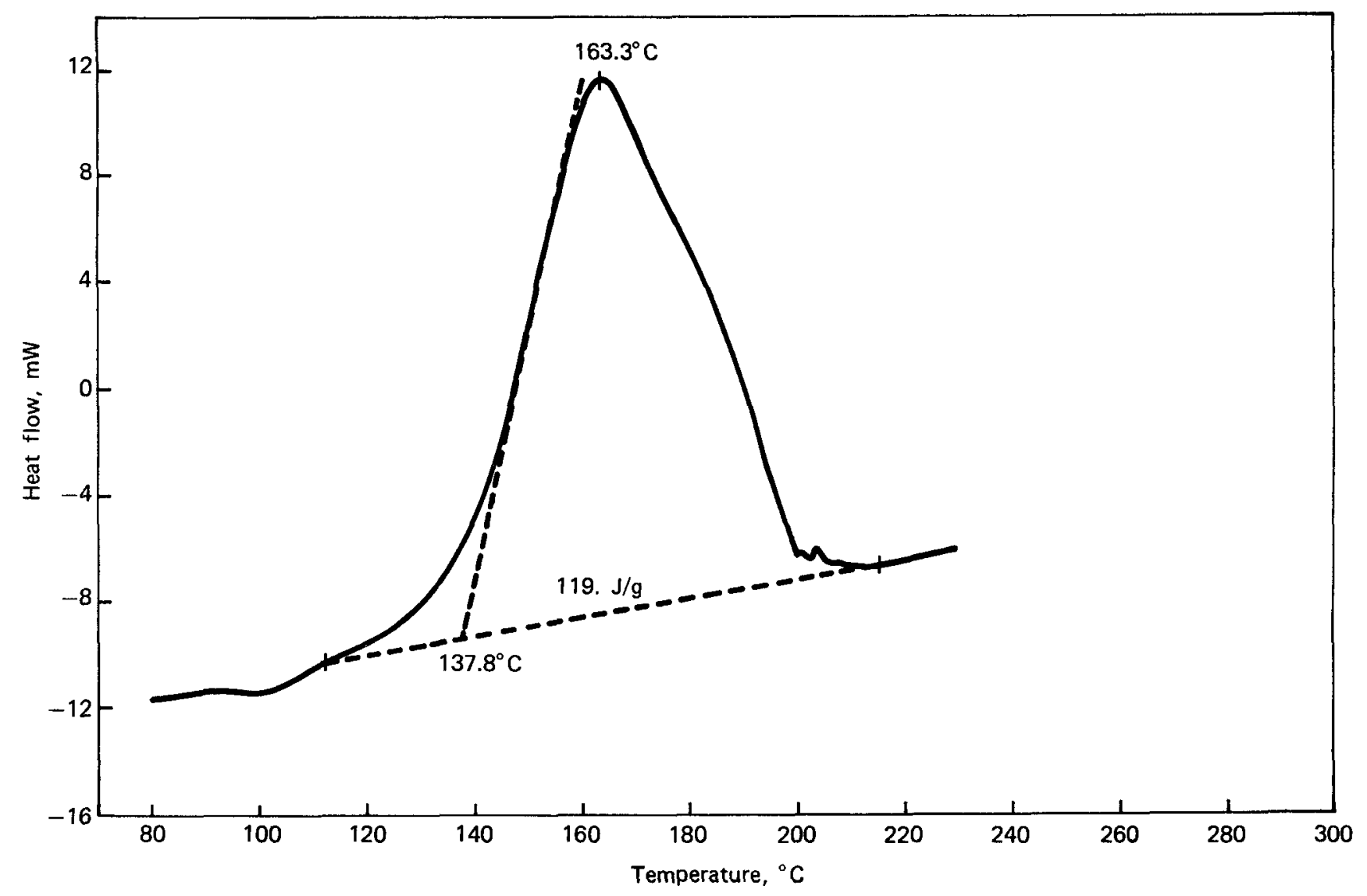

FIGURE 5 - DSC shows loss of inhibitor on processing lowest molecular weight BKC prepolymer (DAPP-14-15) results in premature curing at $-110^{\circ} \mathrm{C}$. 
molding prepared from the Osaka and BKC prepolymers are given in Table 4 , in comparison with those of the FMC Dapon 35-FG compound. The molding conditions and number of test specimens (two per test, unless otherwise indicated) are also given. The changes in molding conditions used for compounds \#580,581, 582, and 583 were based on results of a molding/DSC study on \#581, which showed that the thinner test specimens (arc resistance and tensile bar) were only 75-80\% cured, when molded under the lower temperature conditions, but were $\geq 958$ cured at the higher temperatures. There were no significant differences in physical properties, however, based on the results obtained with compound \#581. The differences in degree of cure were apparently not a factor in the variable arc resistance test results obtained. Failure of the arc resistance test by these DAP-FG molding compounds was therefore not considered to be related to any properties of the prepolymers themselves, and will be the subject of a further separate investigation.

Aside from arc resistance, the only prepolymer in a molding compound which did not pass all other test requirements was BKC's DAPP-14-15, the lowest molecular weight prepolymer. The effect of molecular weight is particularly evident in the failure of the heat distortion test, even in the second formulation (compound \#580). It is, therefore, considered unsatisfactory both in properties and processing.

Ideally, to achieve more accurate and optimum physical property values for any of the DAP-FG molding compounds tested, a separate molding study would be performed on each, and a larger number of test specimens used. Materials limita- tions precluded that in this study, however.

Table 5 contains the most significant results of chemical testing of these molding compounds. Emission spectroscopic analyses did not show any elements present in amounts that could be detrimental (e.g., especially iron or barium) in actual products. The amount of total and free chlorides present is also important, particularly to corrosion prevention. Two BKC prepolymers had higher than desirable levels of total chloride, due to the addition of a halogen-containing chain transfer agent in the polymerization reaction [1]. This problem can be overcome by not using any halogenated chain transfer agents in the polymerization.

Overall, the properties of all of the BKC and Osaka prepolymers in DAP-FG molding compounds were satisfactory, with the exception of the lowest molecular weight prepolymer, DAPP-14-15.

\subsection{Conclusions}

From the results of this study, the following conclusions were drawn:

1) The three Osaka prepolymers tested are all close to one another in molecular weight and MWD, but somewhat lower in both than the FMC Corporation's Dapon 35 tested here. They are slightly higher in monomer content, however.

2) All three Osaka prepolymers processed readily into DAP-FG molding compounds and passed required physical property tests. Because they have lower molecular weights and/or higher monomer contents, additional "Bstaging" polymerization may be required 
Table 4 - PROPERTIES OF O-DAP PREPOLYMERS IN SHORTGLASS-DAP MOLDING COMPOUNDS

\begin{tabular}{|c|c|c|c|c|c|c|c|c|c|c|c|}
\hline Iest or Property & $\begin{array}{c}\text { \#554 } \\
\text { FMC-Dapon } 35 \\
(\text { (OC23797) } \\
\end{array}$ & $\begin{array}{c}\$ 565 \\
\text { Osaka } \\
\text { Sample I }\end{array}$ & $\begin{array}{l}\# 576 \\
\text { Osaka } \\
\text { Lot 7421 } \\
\text { Tot }\end{array}$ & $\begin{array}{l}\# 577 \\
\text { Osaka } \\
\text { Lot } 8566 \\
\end{array}$ & $\begin{array}{l}\text { \#581 } \\
\text { Osaka } \\
\text { Iot } 8566 \\
\end{array}$ & $\begin{array}{c}\# 578 \\
\text { BKC } \\
\text { DAPP 14-15 }\end{array}$ & $\begin{array}{l}\# 580 \\
\text { BKC } \\
\text { DAPP 14-15 }\end{array}$ & $\begin{array}{c}\# 575 \\
\text { BKC } \\
\text { DAPP \#111 }\end{array}$ & $\begin{array}{c}\# 582 \\
\text { BKC } \\
\text { DAPP \#40 I }\end{array}$ & $\begin{array}{c}\$ 583 \\
\text { BKC } \\
\text { DAPP \#39 }\end{array}$ & $\begin{array}{l}\text { Minimm } \\
\text { Acoeptable } \\
\text { Values for } \\
\text { Certification }\end{array}$ \\
\hline Ash content, wt \& & 42.9 & 42.6 & 42.9 & 43.4 & 43.1 & 43.2 & 45.6 & 44.5 & 44.3 & 43.2 & - \\
\hline Volatiles, wt \& & 0.49 & 0.55 & 0.75 & 0.51 & 0.63 & 0.28 & 1.3 & 0.91 & 1.3 & 1.4 & - \\
\hline $\begin{array}{l}\text { Pheometer: } \\
\text { Mun. Torque, in. - - b } \\
8 \text { of Max. after } 3 \text { min }\end{array}$ & $\begin{array}{r}5 \\
95\end{array}$ & $\begin{array}{r}4 \\
97\end{array}$ & $\begin{array}{r}4 \\
99\end{array}$ & $93^{a}$ & $\begin{array}{r}4 \\
92\end{array}$ & $2^{2^{a}}$ & $\begin{array}{r}9 \\
97\end{array}$ & $\begin{array}{r}4 \\
93-99\end{array}$ & $\begin{array}{r}5 \\
97\end{array}$ & $\begin{array}{r}4 \\
97\end{array}$ & $\begin{array}{c}4-15(\text { in } 1.5 \mathrm{~min}) \\
908\end{array}$ \\
\hline $\begin{array}{l}\text { Tensile Strength, } \\
\text { lb/in. }{ }^{2} \text {-ASTM D651 }\end{array}$ & $6590^{C}$ & $6720^{c}$ & $6350^{C}$ & $8330^{C}$ & $\begin{array}{l}5600^{\mathrm{d}} \\
5240^{\mathrm{e}}\end{array}$ & $5630^{\mathrm{C}}$ & $5700^{d}$ & $5780^{c}$ & $4560^{b, d}$ & $5650^{\mathrm{d}}$ & 4500 \\
\hline $\begin{array}{l}\text { Notched Izod } \\
\text { Impact Strength, } \\
\text { ft-1b/in. notch } \\
\text { ASIM D-256A }\end{array}$ & $0.43^{C}$ & $0.52^{C}$ & $0.53^{\mathrm{C}}$ & $0.47^{C}$ & $\begin{array}{l}0.48^{\mathrm{d}} \\
0.50^{\mathrm{e}}\end{array}$ & $0.69^{C}$ & $0.49^{\mathrm{d}}$ & $0.52^{c}$ & $0.35^{\mathrm{d}}$ & $0.34^{\mathrm{d}}$ & 0.30 \\
\hline $\begin{array}{l}\text { Arc Resistance, } \\
\text { Sec., ASTM D-495 }\end{array}$ & $122^{\mathrm{C}}$ & $121^{C}$ & $82^{a, c}$ & $76^{\mathrm{a}}$. & Fails ${ }^{\mathrm{d}, \mathrm{e}}$ & $78^{a, c}$ & Fails ${ }^{\mathrm{d}}$ & $124^{\mathrm{C}}$ & Fails ${ }^{d}$ & Fails ${ }^{d}$ & 115 \\
\hline $\begin{array}{l}\text { Heat Distortion Temp., } \\
{ }^{\circ} \mathrm{C} \text {, ASTM D } 648\end{array}$ & $170^{c}$ & $165^{c}$ & $177^{c}$ & $167^{\mathrm{C}}$ & $170^{\mathrm{d}, e}$ & $147^{a, c}$ & $152^{a, d}$ & $175^{\mathrm{C}}$ & $172^{\mathrm{d}}$ & $173^{\mathrm{d}}$ & 160 \\
\hline $\begin{array}{l}\text { Mesa Spiral } \\
\text { Flow, in.b }\end{array}$ & 11.0 & 19.5 & 25.0 & 24.0 & -- & 40.5 & 11.5 & 24.0 & 9 & 14 & Varies \\
\hline $\begin{array}{l}a_{\text {Fails test }} \\
\text { bone specimen only } \\
{\text { CMolded } 8 \mathrm{~min} / 136-140^{\circ} \mathrm{C}} \\
\mathrm{d}_{\text {Molded } 8 \mathrm{~min} / 150^{\circ} \mathrm{C}} \\
\mathrm{e}_{\text {Molded } 12 \mathrm{~min} / 136-140^{\circ} \mathrm{C}}\end{array}$ & & & & & & & & & & & - \\
\hline
\end{tabular}


Table 5 - CHEMICAL ANALYSES OF DAP-FIBERGIASS MOLDING COMPOUNDS

\begin{tabular}{|c|c|c|c|c|c|c|}
\hline \multicolumn{2}{|c|}{$\begin{array}{l}\text { DAP prepolymer } \\
\text { in molding compound }\end{array}$} & \multirow{2}{*}{$\begin{array}{l}\text { Molding } \\
\text { corpound } \\
\text { number } \\
\end{array}$} & \multicolumn{2}{|c|}{$\begin{array}{l}\text { Elements by emission } \\
\text { spectroscopy } \\
\text { (wt } 8 \text { ) }\end{array}$} & \multirow{2}{*}{$\begin{array}{l}\text { Total chlorides a } \\
\text { wt } 8 \text {, } \\
\text { (includes bromine) }\end{array}$} & \multirow{2}{*}{$\begin{array}{l}\text { Free } \mathrm{Cl}- \\
\text { (wt } 8 \text { ) }\end{array}$} \\
\hline Source & Designation & & Iron & Bariún & & \\
\hline FMC Corporation & $\begin{array}{l}\text { Dapon } 35 \\
\text { (QC \#23797) }\end{array}$ & 554 & 0.2 & 0.02 & 0.03 & 0.001 \\
\hline \multirow[t]{3}{*}{ Osaka Soda } & $\begin{array}{l}\text { Daiso } 35 \\
\text { Sample \#I }\end{array}$ & 565 & 0.3 & 0.04 & 0.03 & 0.001 \\
\hline & Lot 7421 & 576 & 0.2 & 0.02 & 0.04 & $<0.001$ \\
\hline & Lot 8566 & 577 & 0.2 & 0.02 & 0.03 & $<0.0002$ \\
\hline \multirow[t]{4}{*}{ Bendix } & DAPP-14-15 & 578 & 0.3 & 0.02 & 0.01 & $<0.0002$ \\
\hline & DAPP-11 & 575 & 0.3 & 0.05 & 0.005 & 0.001 \\
\hline & DAPP-40 & 582 & 0.2 & 0.03 & $0.39^{\mathrm{a}}$ & 0.0007 \\
\hline & DAPP-39 & 583 & 0.2 & 0.02 & $\left.\begin{array}{l}0.41 \\
0.38\end{array}\right\} a$ & $<0.001$ \\
\hline
\end{tabular}

to achieve lower spiral flow values.

3) As expected, the four BKC prepolymers varied widely in $M_{W}$ and MWD, from very low in both to much higher than FMC's Dapon 35. The two intermediate molecular weight prepolymers approached the Osaka prepolymers and FMC's Dapon 35 in MWD. Monomer content varied, but not in direct relation to molecular weight, and most were significantly higher than the Dapon 35.

4) The processability and, to some extent, the properties of the BKC prepolymers in DAP-FG molding compounds depended very much on $M_{W}$ and MWD values. The lowest $M_{W}$ prepolymer was unsatisfactory in both processing and properties, whereas the highest $M_{w}$ prepolymer was difficult to dissolve, but satisfactory in properties.

5) Based on these results, it is possible to establish guidelines (in terms of ranges of $\mathrm{M}_{\mathrm{W}}$ and MWD values as determined here) for diallyl phthalate pre- polymers to produce acceptable DAPfiberglass molding compounds. Acceptable DAP monomer content limits in the prepolymers are less certain, but may be given approximately. These ranges or limits are as follows:

a) $\mathrm{M}_{\mathrm{w}}-\geq 30,000$ and $\leq 150,000$

b) MWD $\left(M_{W} / M_{n}\right)-\geq 3.0$ and $\leq 18.0$ (Both of the above are relative to the monodisperse polystyrene standards used here.)

c) DAP monomer contents $-\geq 1.0$ and $\leq 6.0$ wt 8

6) From the results of this study, it is reasonable to extrapolate to the production of DAP-asbestos and DAPOrlon molding compounds, which are similar. Those prepolymers producing satisfactory DAP-FG molding compounds should also produce satisfactory DAPasbestos and DAP-Orlon compounds, with only some minor adjustments in 
formulation or processing required. Such a test of one of Osaka prepolymers (lot 8566), has now been completed. It was processed without difficulty into both DAP-asbestos and DAP-Orlon molding compounds, on a production scale. Both molding compounds have also passed all physical tests required for certification. Results for asbestos-DAP are given in Table 6.

Based on this study and the Bendix prepolymer synthesis effort, there now appear to be two alternatives to the use of FMC's Dapon 35 o-DAP prepolymer in Mound's production of DAP molding compounds. First, for interim use, the Osaka o-DAP prepolymers appear to be acceptable. Second, for the longer term, BKC prepolymers, similar to their two intermediate molecular weight DAP prepolymers, should be usable. If the scale-up of the laboratory process by Bendix is successful, a domestic source of the prepolymer would be ensured.

\section{Future Work}

Bendix-Kansas City is now beginning a project to scale up the laboratory synthesis of o-DAP prepolymers. As sufficient quantities of prepolymer become available, they will be tested in asbestos, orlon, and fiberglass compounds at Mound. This work, if successful, will ensure a long-term domestic source of DAP prepolymer for DOE. In the interim, the osaka o-DAP prepolymer will be used.

Characterization of DAP prepolymers will continue. Determination of the total and pendant allyl groups and their correlation with "good" molding compound properties will be investigated. Thermal analyses will be utilized to better define transition temperature and curing behavior of prepolymers and molding compounds. Other methods of structural characterization may also be investigated.

Table 6 - PHYSICAL TEST RESULTS FOR OSAKA DAP-ASBESTOS MOLDING COMPOUND

Physical Test

Tensile strength, psi ASTM D651-75

Compressive strength, psi ASTM D695-79

Izod impact strength,

$\mathrm{ft}-1 \mathrm{~b} / \mathrm{in}$. of notch

ASTM D256-78

Heat distortion, ${ }^{\circ} \mathrm{C}$ ASTM D648-72

Arc Resistance, sec ASTM D495-73

Rheometer:

Min./torque, in-lb

$\left(1.2 \mathrm{~min} / 300^{6} \mathrm{~F}\right.$ )

吾 $\operatorname{Max} ., 3 \mathrm{~min} / 300^{\circ} \mathrm{F}$
Minimum Acceptable Value

5000

20,000

0.200

150

120

$5-20$

90

\begin{tabular}{cc}
\multicolumn{2}{c}{$\begin{array}{c}\text { Asbestos-DAP } \\
\text { No. of }\end{array}$} \\
Test Specimens & $\begin{array}{c}\text { Average } \\
\text { Value }\end{array}$ \\
\hline 10 & 5970
\end{tabular}

5

24,560

5

0.255

177

141

15

94 


\section{Acknowledgements}

The authors would like to acknowledge the contributions of the following individuals to this work: Dr. G. K. Baker and

B. G. Parker of Bendix-Kansas City for supplying the BKC prepolymers; Dr. Chin Iu of Cosmic Plastic for supplying the osaka prepolymer samples; and the Mound Analytical department, in particular L. W. Laymon and G. E. Hapner, for obtaining the physical/chemical property test data on the DAP-FG molding compounds.

\section{References}

1. G. K. Baker and B. G. Parker, "Synthesis and Characterization of Diallyl Phthalate Prepolymers," BID-A334, August 1982 .

2. R. B. Whitaker, J. E. Glaub, N. R. Bonekowski, and P. D. Gillham, "Characterization of Fiberglass - Filled Diallyl Phthalate Molding Resins and Molded Parts," MLM-2766, December 1, 1980,25 pp.

3. P. E. Willard, J. Macromol. Sci. Chem., A8, 1, 33 (1974). 


\section{Distribution}

EXTERNAL

TIC, UC-25 (216)

J. N. Boyer, DOE, Dayton Area office

H. N Hill, DOE, Dayton Area Office

R. S. George, DOE, AL

M. Q. GuY, DOE, AI

H. A. Schneiderman, Monsanto, St. Louis

M. Theisen, DOE-ORO

H. L. Williams, Monsanto, St. Louis

Monsanto Reports Library, R2C, St. Louis

E. I. DuPont, Savannah River

J. M. Stone

Los Alamos National Laboratory

F. W. Dubois

D. Dunning

R. N. McCormick

J. A. Freed

W. Meyers

D. MacMillan

J. V. Milewski

W. A. May

S. E. Newfield

G. W. Taylor

Lawrence Livermore National Laboratory

H. A. Golopol

D. M. Hoffman

J. R. Kolb

$\mathrm{J}$. Lepper

R. Morgan

P. M. Naillon

A. J. Pane

L. E. Lorensen

D. L. Seaton

J. B. Verity
Sandia National Laboratories, Livermore

A. West

Sandia National Laboratories, Albuguergue

J. G. Curro

J. W. Mead

L. A. Harrah

J. E. Kennedy

R. J. Martinez

S. E. Klassen

J. Sayre

A. Kraynik

Union Carbide, Y-12 Plant

S. W. Brown R. Schede

J. R. Day R. G. Thompson

G. F. Dorsey W. E. Tewes

N. Dow

A. G. Martin

J. E. White

H. D. Whitehead

Bendix, Kansas City Division

G. K. Baker

J. W. McFarland

C. H. Smith

B. G. Parker

R. E. Smith

R. L. Sadler
D. A. Young

Mason \& Hanger-Silas Mason Co.. Pantex Plant

G. L. Flowers

P. A. Foster

INTERNAL

L. R. Baird

G. L. Ball

D. R. Bohl

R. T. Braun

R. J. Desando

J. V. Dichiaro

M. W. Donnelly

C. F. Draut

T. K. Ferguson

R. A. Fischbein

J. L. Harrison

W. D. Hugo, Jr.

C. W. Huntington

T. Z. Jones
D. P. Kelly

F. D. Lonadier

K. Metzger

G. L. Numbers

D. W. Organ

W. D. Pardieck

R. F. Salerno

R. E. Schneider

R. J. Schumacher

R. J. Seiler

J. A. Thomes

R. Thorpe

R. B. Whitaker

G. R. Wirth

Library (10)

Publications 